\title{
REVERSE OSMOSIS PERFORMANCE WITH SOLUTIONS CONTAINING TRI-N-BUTYL PHOSPHATE (U)
}

by J. L. Siler

WSRC-RP--9 1-1058

Westinghouse Savannah River Company

DE93 008503

Savannah River Site

Aiken, South Carolina 29808

Other Authors: N/A

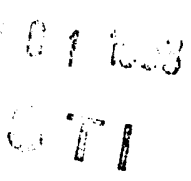

This paper was prepared in connection with work done under Contract No. DE-AC09-89SR18035 with the U. S. Department of Energy. By acceptance of this paper, the publisher and/or recipient acknowledges the U.S. Gav Jrnment's right to retain a nonexclusive, royalty-free license in and to any copjright covering this paper, along with the right to reproduce and to authorize others to reproduce all or part of the copyrighted paper. 


\section{DISCLAIMER}

This report was prepared as an account of work sponsored by an agency of the United States Government. Neither the United States Government nor any agency thereof, nor any of their employees, makes any warranty, express or implied, or assumes any legal liability or responsibility for the accuracy, completeness, or usefulness of any information, apparatus, product, or process disclosed, or represents that its use would not infringe privately owned rights. Reference herein to any specific commercial product, process, or service by trade name, trademark, manufacturer, or otherwise does not necessarily constitute or imply its endorsement, recommendation, or favoring by the United States Government or any agency thereof. The views and opinions of authors expressed herein do not necessarily state or reflect those of the United States Government or any agency thereof.

This report has been reproduced directly from the best available copy.

Available to DOE and DOE contractors from the Office of Scientific and Technical Information, P. O. Box 62, Oak Ridge, TN 37831; prices available from (615) $576-8401$.

Available to the public from the National Technical Information Service, U. S. Department of Commerce, 5235 Port Royal Rd., Springfield, VA 22161. 
Keywords: Membrane Fouling, TBP, E/H ETE, Reverse

Osmosis, water Flux, Salt

Rejection, DF

Retention Time: Permanent

October 22, 1991

TO: D. L. Eish, 773-A

From: J. L. Siler, 676-T\& $\mathcal{L}$

Reverse esmesis Performance with solutions

Containing Tri-n-butyl Phosphate(U)

\section{SUMMARY}

Tests were conducted to determine whether the reverse osmosis (RO) units at the F/H Effluent Treatment Facility (ETE) could be made to process solutions containing tri-n-butyl phosphate (TBP). It was desired to test whether operation at a feed $\mathrm{pH}$ other than neutral would improve performance. Tests results indicate that little improvement in the water flux can be expected at other pH values. Flux losses approached 35-50\% after nine cycles of processing feed containing TBP and insoluble metals. However, salt rejection was very good in all cases. Flow-averaged DF values increased from 20 to $44-49$ (at 90\% water recovery) after processing.TBP: Sodium rejection was measured to be $>99.5 \%(D E=200)$ in several instances. The water flux was restored to prefouled levels by chemically cleaning the membrane with a pH=1.8 oxalic acid solution at $200 \mathrm{psi}$ and $30^{\circ} \mathrm{C}$.

The flux losses observed could not be tolerated with the present ETF system. The possibility of higher feed salt content (perhaps $10,000 \mathrm{mg} / 1$ as compared to $1,500-2,000 \mathrm{mg} / 1$ nominal) would result in insufficient processing capability. Additional membranes and pumping capacity would be required. However, the increased salt rejection would be a benefit, in light of the poos DFs typically observed at the ETE.

Pilot-scale Ro testing in the ETF would enable a more realistic evaluation to be made of the DF benefits from addition of small quantities of TBP in the RO inlet. The potential gain in salt DF and elimination of the biofouling problem would reduce operation costs (due to reduced RO cleaning \& downtime) and help offset the capital costs for additional membrane area. 


\section{INTRODUCTION}

Tri-n-butyl phosphate (TBP) is present in the wastewater that is processed at the $\mathrm{F} / \mathrm{H}$ Effluent Treatment Facility (ETE). Earlier work [e.g., Piper (1987) or Poy (1987)] indicated that the combination of TBP and low levels of insoluble inorganics resulted in severe membrane fouling. Flux losses of 40-50\% were observed. Additionally, chemical cleaning with 1-2\% oxalic acid solutions was required. Operating the membranes on TBP-free solutions resulted in minimal flux losses.

TBP is removed from the membrane feed by granulated activated carbon beds. The carbon beds are protected from $\mathrm{Hg}$ adsorption by a Hg-specific resin bed immediately upstream. The presence of the carbon and resin beds in the ETF results in bacteria being sloughed off and sent to the downstream membranes, which are then fouled severely. Marginal success has been achieved in restoring the membranes to pre-fouled conditions.

IWT proposed that the membrane system could be made to function on TBP-containing feed solutions. This ability would mean that the resin/carbon bed bioreactors could be removed from the RO pretreatment portion of the ETF.. However, the TBP must be removed prior to environmental discharge due to the oil \& grease limit imposed (TBP shows a positive in this test). TBP removal could be accomplished by processing the evaporator overheads (which would contain the TBP concentrate from the RO process) downstream of the membranes. Any bacteria that sloughed off the resin/carbon beds would pass harmlessly to the environment. Also, bacterial growth on the beds at this location in the process should be slower, because: a) there would be minimal amounts of nitrate in this stream and b) this water should be relatively sterile.

\section{EXPERIMENTAL PROCEDURE}

A simulant containing (in $\mathrm{mg} / 1$ ) Al-1.0, Fe-0.2, Si-2.4, NaNO32,000 , and TBP-50 was used in these tests. Membrane performance and stability was measured with a $2,000 \mathrm{mg} / 1$ NaNO 3 solution. The basic experimental procedure was outlined in report \#WSRC-RP-91431. Detailed operating instructions can be found in TNX operating procedure \#679T90039.

\section{RESULTS AND DISCUSSION}

The water flux results for processing TBP-containing solutions at $\mathrm{pH}=3$ and 11 are shown in Figures 1 and 2 , respectively: The water flux values at $\mathrm{pH}=11$ were higher than were obtained at $\mathrm{pH}=3$. For example, the second TBP cycle resulted in dimensionless flux ratios of $0.9-0.75$ (at. $\mathrm{pH}=11$ ) and $0.78-0.65$ (at $\mathrm{pH}=3$ ) for water recoveries of $0-90 \%$. The flux loss eventually stopped increasing, as shown in Figure 1. The water flux appeared to asymptotically approach 40-45\% loss after nine TBP cycles were completed. This is a substantial loss, but the encouraging result is that process- 
ing a pure salt solution after the nine TBP cycles resulted in very similar results to those obtained prior to TBP addition. This indicates that the lasting impact of TBP on the membrane is small, and that no permanent flux loss occurs. This was not the case for the tests conducted at $\mathrm{pH}=6$ and 11 (Eigure 2). The water flux values for the pure salt solutions processed after several TBP cycles at $\mathrm{pH}=6$ and 11 were about $20 \%$ lower than the initial results before TBP was added. The $\mathrm{pH}=3$ test resulted in about $5 \frac{5}{3}$ flux loss by comparison. The flux loss can be overcome by increasing the membrane area approximately $80 \%$ to offset the $45 \%$ flux loss. Also, higher pressure pumps would increase the treated water capacity of the present membrane system at the ETF.

The membrane appears to be stable in the presence of TBP. The water flux can always be restored by cleaning the membrane in a 1-2\% oxalic acid solution. It appears that TBP adsorbs on and in the membrane, and restricts the flow passages through the membrane.

The reduction in flow path reduces the water flux, but forms a dynamic membrane which increases the resistance to salt passage. Salt rejections of over $99.5 \%(D E=200)$ were measured. The DF performance is summarized in Figure 3. The DF was generally above 400 at lower water recoveries and approached 200 at $85-90 \%$ water recovery. It should be noted that the DEs for the "Salt only" cycle are for conductivity and not sodium. However, the two parameters generally track one another quite well.

The potential DF benefits warrant further testing of this approach at the ETF. A pilot RO system at the ETF would enable confirmation of these tests on the real feed rather than on simulants. Also, a pilot system would allow destructive testing to be performed.

The important concept about modifying the ETF RO system to process TBP is that this would mitigate the bacterial fouling problem. The resin and carbon beds could be placed downstream of the membranes to remove the steam-stripped TBP $f$ :om the evaporator overheads.

\section{CONCLUSIONS}

Little improvement in the Ro membrane's flux performance on TBPcontaining solutions was noted as a function of feed $\mathrm{pH}$. All pH values resulted in about 35-50\% flux loss. Chemical cleaning of the membrane was required to restore performance. However, there was a significant improvement in the membrane's $D F$ performance following TBP addition when the feed was processed at $\mathrm{pH}=3$. Salt rejection was very good $[>99.5 \% \quad(D F=200)$ in many instances], plus very little flux loss remained after TBP was removed from the solution. The flux loss appeared to be essentially reversible at $\mathrm{pH}=3$. 
These results indicate that additional membrane area might allow feeds containing TBP to be processed at the ETF. Thus, the RO biofouling problem could be eliminated by relocating the resin/carbon beds to process the evaporator overheads for TBP removal.

These tests were performed in an effort to eliminate the RO biofouling problem. Additional reports are being generated in support of work completed on this project. An overall summary of the total project with recommendations will follow.

\section{QUALITY ASSURANCE}

The work described in this report was performed according to the guidelines in the SRS QA manual. The data collected during these tests were recorded in laboratory notebook \#WSRC-NB-90-257.

\section{REFERENCES}

Piper, D. G., "F\%H Effluent Treatment Facility ECWPE Pilot Test", DPST-87-636, 1987 .

Poy, F. I., Unpublished Data, 1987.

Siler, J. L., "The Influence of Bacteria on Reverse Osmosis Performance at the $\mathrm{F} / \mathrm{H}$ Effluent Treatment Facility - A Preliminary Investigation(U)", WSRC-RP-91-431, April 10, 1991.

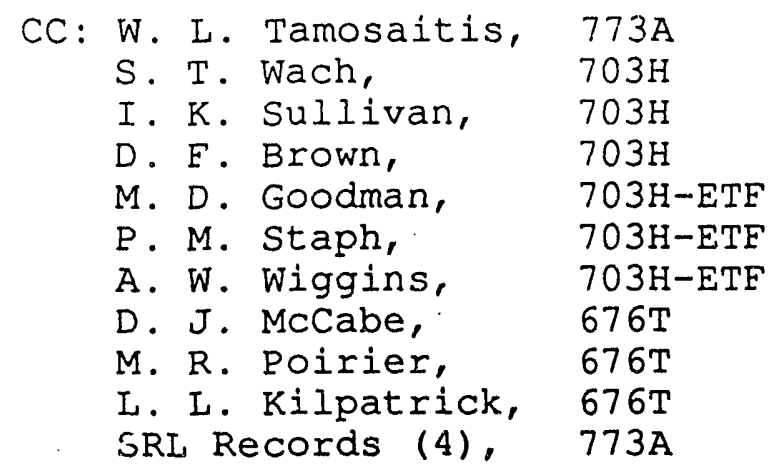



D. I. FISH

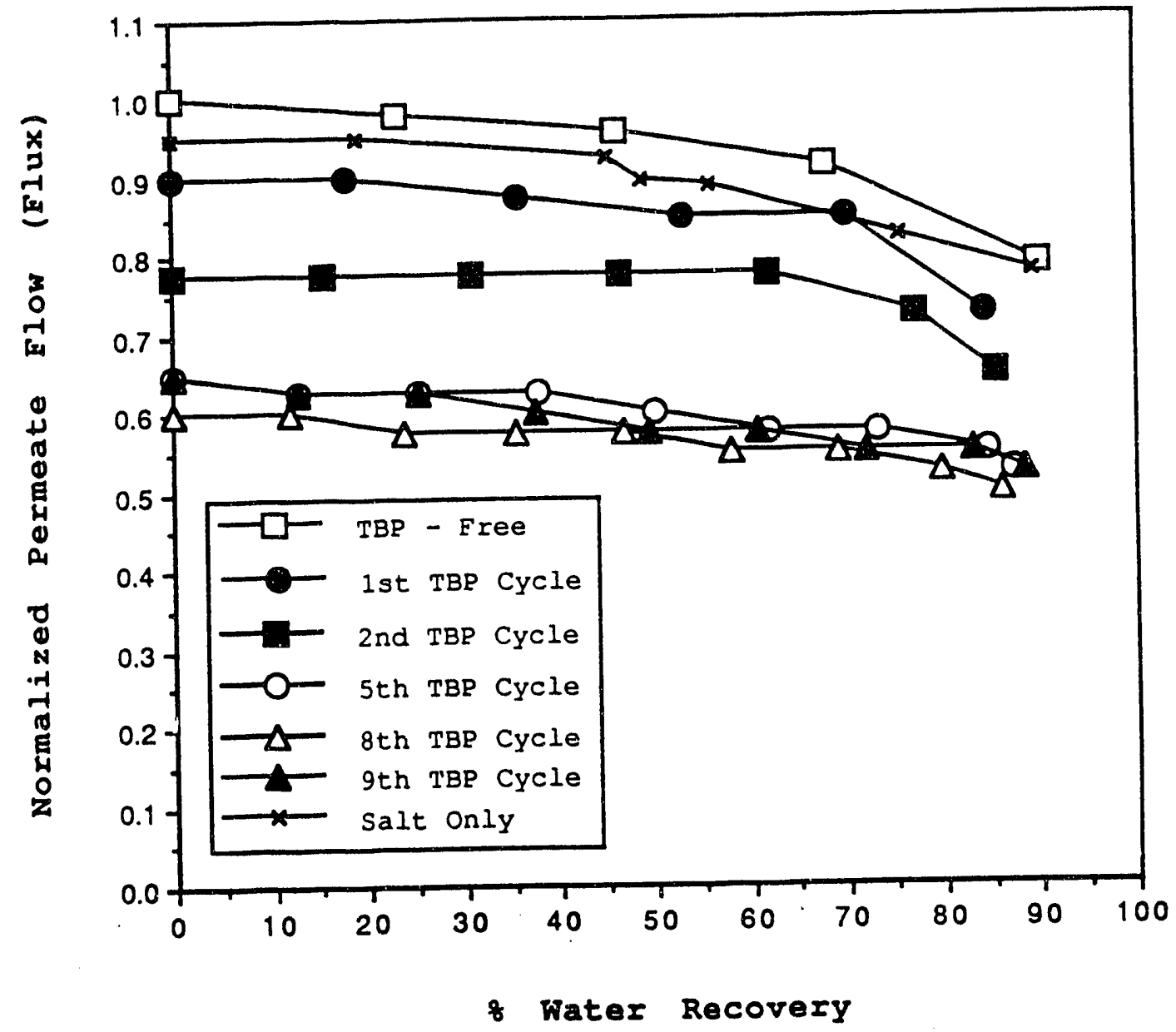

Figure 1. RO Performance at $\mathrm{pH}=3$ for a solution of $50 \mathrm{mg} / \mathrm{I}$ TBP and Metals. 


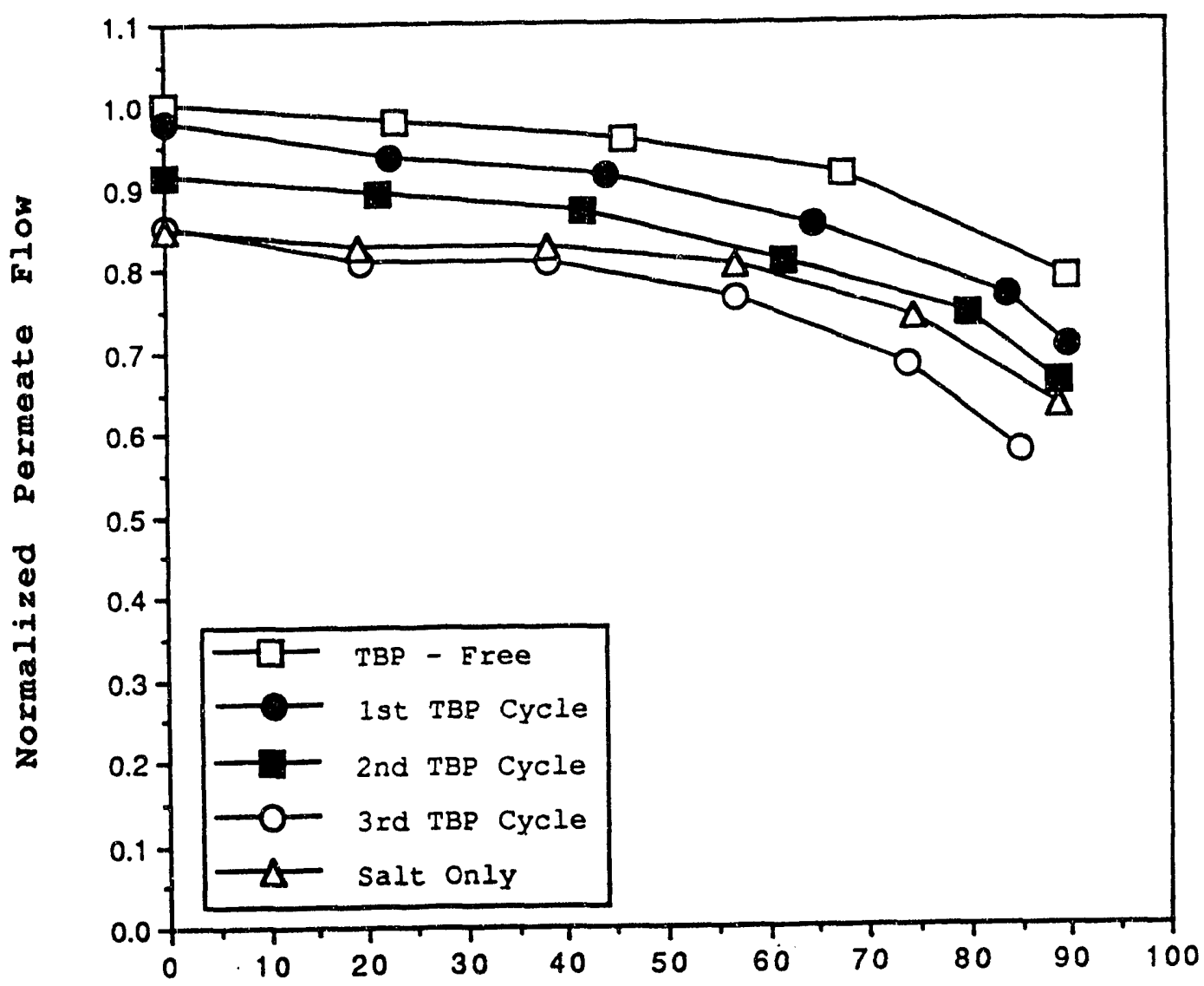

\& water Recovery

Figure 2. Ro Performance at $\mathrm{pH}=11$ for a solution of $50 \mathrm{mg} / 1 \mathrm{TBP}$ and Metals. 


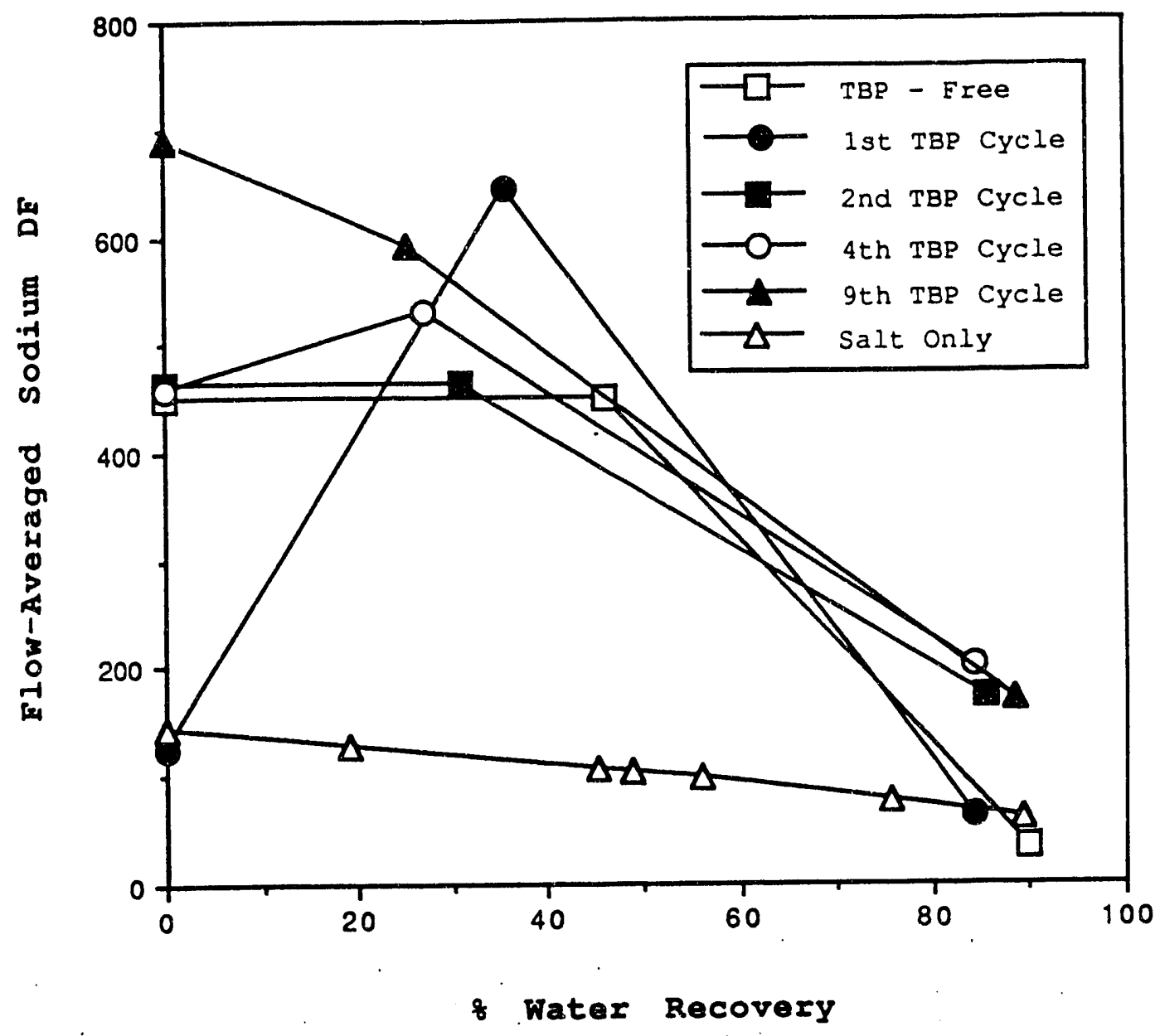

Figure 3: Membrane DE Performance at $\mathrm{pH}=3$ with TBP Present. 

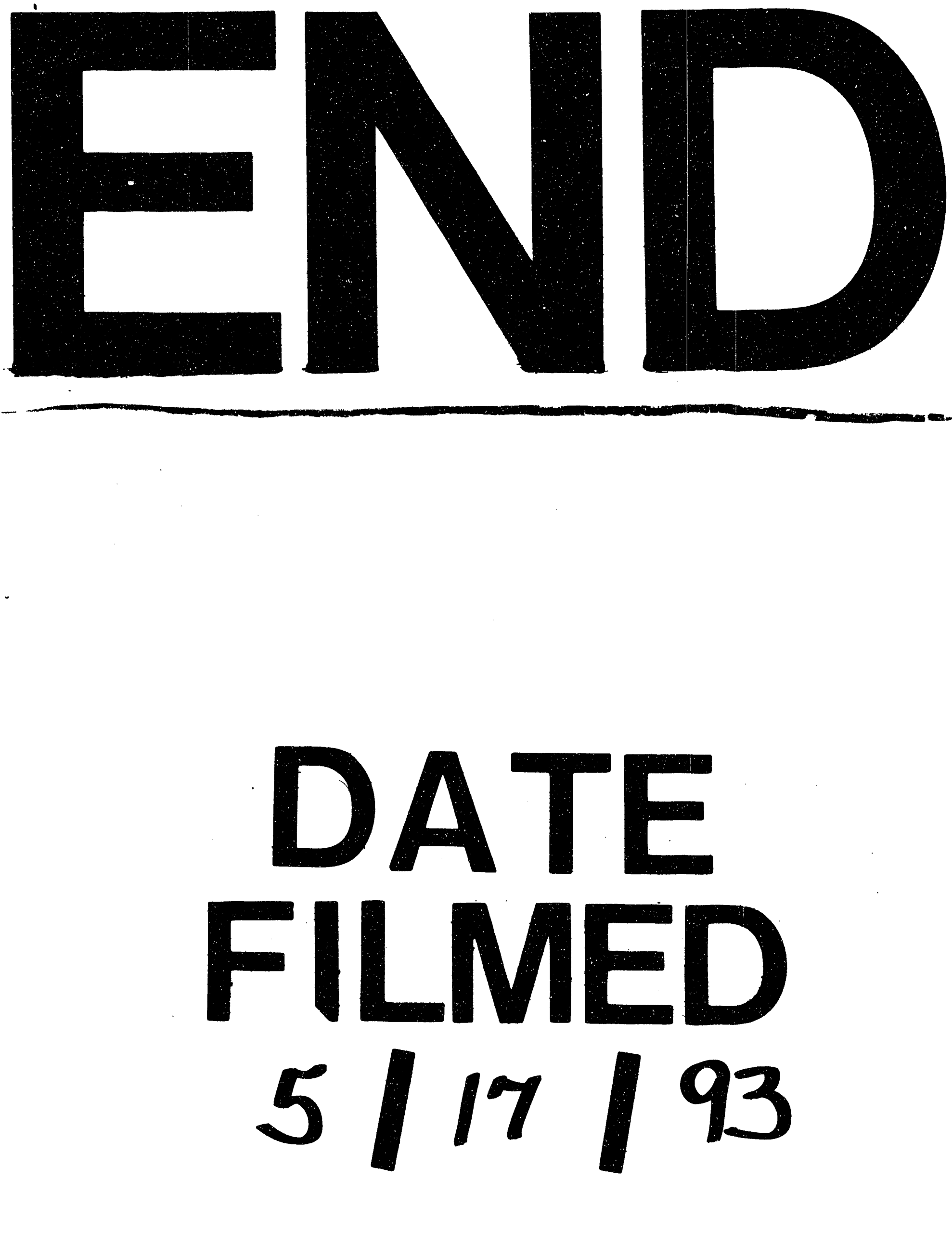


\section{.}

